\title{
Financial Integration Among the ASEAN 5 + 3 Stock Markets: \\ A Preliminary Look at the First 10 Years of the New Millenium
}

\author{
Leila C. Kabigting \\ University of Guam, Guam, USA \\ Rene B. Hapitan \\ iACADEMY School of Business, Manila, Philippines
}

\begin{abstract}
The purpose of this study is to investigate the financial integration of the stock markets of the ASEAN $5+3$ countries. These countries include Indonesia, Malaysia, Philippines, Singapore, Thailand, China, Japan, and South Korea. The research determined the stock return volatility for each country's index during the first decade of the new millennium. The findings showed that there is the presence of integration and co-integration with Philippine index's return with the index's returns of the following countries: Indonesia, Singapore, and Thailand. Furthermore, there is evidence of volatility clustering in these stock markets. The study concluded with the policy implications of greater integration in light of the planned cross trading among four ASEAN bourses, namely, Philippines, Singapore, Thailand, and Malaysia by 2012.
\end{abstract}

Keywords: ASEAN 5 + 3, financial integration, stock markets, stock return volatility, global financial crisis, cross border ownership

\section{Introduction}

The European Commission defined financial integration as the countries' national financial markets that act separately and eventually, become one interrelated financial market, affected by prices, and the cooperation among these markets. Furthermore, the European Commission cited the advantages brought by financial integration are efficiency and proficiency among the service providers. It also discussed that financial integration may result in an increase in cross border ownership, also a possibility of contagion risks (2005, as cited in Jang, 2011).

Rizavi, Naqvi, and Rizvi (2011) cited Kose, Prasad, Rogof, and Wei (2006) and Quinn, Schindler, and Toyoda (2011) discussed the measurements for financial integration, which can be classified into three: (1) de jure measures; (2) de facto (further classified as price-based measures and quantity-based measures); and (3) hybrid (combination of de jure and de facto).

Rizavi, Naqvi, and Rizvi (2011) studied the Asian economies particularly the stock market indices of: China, Hong Kong, India, Indonesia, Malaysia, Pakistan, Philippines, Singapore, South Korea, Thailand and

Leila C. Kabigting, Doctor of Business Administration, Associate Professor of Finance, School of Business and Public Administration, University of Guam.

Rene B. Hapitan, Master in Business Management, iACADEMY School of Business.

Correspondence concerning this article should be addressed to Dr. Leila C. Kabigting, University of Guam, P.O. Box 5169 UOG Station, Mangilao, Guam, 96923, USA. E-mail: lckabigting@uguam.uog.edu. 
Merrill Lynch Major 11 International Index-EUX as proxy for world market from 1999 to 2009 to determine if there was global integration in the financial markets of Asia and the speed of integration. Using the two price-based measures of the level of financial integration, beta, and sigma convergence concepts, their results showed that there was an increase in the degree of financial integration as evidenced by a gradual increase in the process of convergence returns and that the emerging markets of Asia are integrated regionally with the world. However, the results showed it was moving farther away from -1 , which showed more overall divergence than convergence.

A related study, Karim and Majid (2010) used weekly stock indices from January 1992 to May 2008 to find out if the Malaysian stock market was integrated with the stock markets of its trading partners (USA, Singapore, Thailand and two of the plus three countries, i.e., China and Japan). The results showed that the stock market of Malaysia and the stock markets of these major trading partners were integrated, due to trade and proximity. The research recommended that there should be more trade liberalization through incentives in trade and investment to increase integration.

Savva and Aslanidis (2010) employed various GARCH methodologies to determine if financial integration existed among five Eastern European countries (Hungary, Czech Republic, Slovakia, Slovenia, and Poland) and the Euro-zone. Their findings showed that the Czech, Slovenian, and Polish markets have increased their correlation to the Euro-zone from 1997 to 2008, because of developments in the region and not due to financial integration.

Morana's (2008) findings showed that global economic shocks among the international stock markets co-movements in the G-7 countries (Japan, USA, Britain, Canada, Germany, Italy, and France) affected economic integration while financial shock spillovers affected regional financial integration. In a similar study, Chittedi (2010) studied the integration of the stock market among the Brazil, Russia, India, and China (BRIC) economies in general and their integration with the developed countries' stock markets such as USA, United Kingdom (UK), and Japan using co-integration as one of the methodologies. The results showed evidence of co-integration between BRIC countries and developed countries, namely, USA, UK, and Japan.

Based on the above literature, there is adequate evidence of financial integration among economies and regions. However, there are varying degrees of this integration to indicate that there are still opportunities for these regions in further improving financial integration among the stock markets of these economies. It should be noted that before the new millennium, the ASEAN region had just emerged from the Asian financial crisis in 1997. And in the new millennium, the subprime crisis and the European debt crisis hampered some of the gains from the just-recovering region.

\section{Methodology and Analysis of Findings}

The study used the monthly indices of the stock markets of the ASEAN $5+3$ from January 2000 to April 2012 (see Table 1) derived from Technistock. Technistock is one of the major providers of information services and technology for the financial markets (Retrieved from http://www.technistock.com). The use of data after 2010 was intended to determine any possible after-decade effects of the global financial crisis.

The study followed by Rizavi, Naqvi, and Rizvi (2011) in calculating return, $R_{i t}$ as the continuously compounding return of each index where daily returns were computed using the natural log of current index (closing prices in domestic currency) over the previous day's values.

$$
R_{i t}=\ln \left(P_{i t} / P_{i t-1}\right)
$$


where $P_{i t}$ is the current index value of the individual country (i) day $(t)$;

$P_{i t-1}$ is the previous day's value of the index of the individual country.

Using the Gretl software, the researchers regressed a sample index, that is the Philippine stock exchange index (PSEI) returns as the dependent variable and the rest of the indices' returns as the independent variables to determine if there is a level of financial integration. The Philippine stock exchange was selected as the dependent variable as it was among the top three best performing markets (37.6\% year-on-year growth) as of the end of the December 2010 (Retrieved from http://www.pseacademy.com.ph/lm/investors details/id-1325765553493/Philippine_stock_market_performance_ 2010.html). The results of the regression are found in Tables 2, 3, 4, 5, and 6.

Table 1

National Indices

\begin{tabular}{|l|l|}
\hline Country & Index \\
\hline China & Shanghai Composite Index (SSE) \\
\hline Indonesia & Jakarta Stock Exchange Composite Index (JCI) \\
\hline Japan & Nikkei Stock Average 225 (N225) \\
\hline Malaysia & Kuala Lumpur Composite Index (KLCI) \\
\hline Philippines & Philippine Stock Exchange Index (PSEi) \\
\hline Singapore & Singapore Straits Times Index (STI) \\
\hline South Korea & Korea Stock Exchange Kospi Index (KOSPI) \\
\hline Thailand & The Stock Exchange of Thailand (SET) \\
\hline
\end{tabular}

Tables 2 and 3 provide the descriptive statistics of the index's monthly returns for all countries for the years covered. It can be observed that the highest return is 0.242526 (China) and the lowest return is -0.377197 (Indonesia). Shanghai index's returns (China) have the highest standard deviation (0.0829505) and KLCI (Malaysia) has the lowest standard deviation (0.0482825) which indicates that there are more volatile shares in the Shanghai's index.

Table 2

Summary Statistics

\begin{tabular}{lllll}
\hline Variable & Mean & Medium & Minimum & Maximum \\
\hline JCIln_returns & 0.0131857 & 0.0227108 & -0.377197 & 0.183417 \\
KLCLNRET & 0.00444272 & 0.0102962 & -0.165142 & 0.127032 \\
KospilnrET & 0.00441258 & 0.0102694 & -0.263112 & 0.202537 \\
Nikkeilnreturns & -0.00464520 & 0.00130186 & -0.272162 & 0.120888 \\
Pseilnreturn & 0.00594930 & 0.0131325 & -0.275382 & 0.153549 \\
Shanghailnretun & 0.00379475 & 0.00797422 & -0.282779 & 0.242526 \\
Singaporelnretu & 0.00124570 & 0.0107747 & -0.273640 & 0.193002 \\
Setlnret & 0.00623019 & 0.0127685 & -0.359188 & 0.212034 \\
\hline
\end{tabular}

All index returns showed that they are negatively skewed, which implies that the return distributions of the shares included in these indices may have earning negative returns, i.e., the release of bad news has more impact than good news determined by Ahmed and Farooq (2008) in their study using returns from the Karachi stock exchange. The same results were similarly obtained by Curto, Pinto, and Tavares (2009) this time using the three series returns of the USA (Dow Jones Industrial Average), German (DAX), and Portuguese (PSI20) 
stock market indices from December 31, 1992, to December 31, 2006. The same study showed that the kurtosis for these returns were greater than three, which indicates they are leptokurtic.

Table 3 shows that the following indices are leptokurtic, Jakarta (Indonesia), Singapore, and Thailand stock exchanges. The value of kurtosis indicates presence of fat tails (Rizavi, Naqvi, \& Rizvi, 2011). Ordinarily, higher kurtosis indicates that the variance could be the result of less extreme deviations from the mean, which in this case implies the markets of these economies are less prone to extreme highs and lows.

Table 3

Summary Statistics

\begin{tabular}{llcll}
\hline Variable & Std. Dev. & C.V. & Skewness & Ex. Kurtosis \\
\hline JCIln_returns & 0.0745718 & 5.65551 & -1.07488 & 3.92977 \\
KLCLNRET & 0.0482825 & 10.8678 & -0.406609 & 0.887027 \\
KospilnrET & 0.0748380 & 16.9601 & -0.430796 & 0.548150 \\
Nikkeilnreturns & 0.0594038 & 12.7882 & -0.749434 & 1.67570 \\
Pseilnreturn & 0.0665148 & 11.1803 & -0.640046 & 1.55853 \\
Shanghailnretun & 0.0829505 & 21.8593 & -0.576552 & 1.37222 \\
Singaporelnretu & 0.0618032 & 49.6131 & -1.01433 & 3.48014 \\
Setlnret & 0.0767453 & 12.3183 & -1.03438 & 3.46966 \\
\hline
\end{tabular}

Tables 4 and 5 show the correlation among the indices' returns. Highest correlation is between Singapore and Indonesia, followed by Singapore and South Korea, Singapore and Thailand, Philippines and Indonesia, Thailand and South Korea, and Thailand and Indonesia.

Table 4

Correlation Coefficients, Using Observations From December 1999 to April 2012

\begin{tabular}{llllll}
\hline JCIln_returns & KLCLNRET & KOSPIlnret & Nikkeilnreturns & Pseilnreturn & \\
\hline 1.0000 & 0.5156 & 0.5692 & 0.5213 & 0.6395 & JCIln_returns \\
& 1.0000 & 0.4138 & 0.3593 & 0.3883 & KLCLNRET \\
& 1.0000 & 0.5989 & 0.5272 & KospilnrET \\
& & 1.0000 & 0.4195 & Nikkeilnreturns \\
& & & 1.0000 & Pseilnreturn \\
\hline
\end{tabular}

Table 5

Correlation Coefficients, Using Observations From December 1999 to April 2012

\begin{tabular}{lllll}
\hline & Shanghailnretun & Singaporelnretu & Setlnret & \\
\hline 0.2627 & 0.6805 & 0.6202 & JCIln_returns \\
0.3647 & 0.5386 & 0.4485 & KLCLNRET \\
0.2786 & 0.6634 & 0.6340 & KospilnrET \\
0.3009 & 0.5885 & 0.5028 & Nikkelnreturns \\
0.2184 & 0.6322 & 0.6003 & Pseilnreturn & Shanghailnretun \\
1.0000 & 0.3189 & 1.0000 & 0.1845 & Singaporelnretu \\
& & & 1.0000 & Setlnret \\
\hline
\end{tabular}

The correlations imply a certain degree of potential integration and investment relationship among these 
countries, aside from the geographical proximity:

- Singapore and Indonesia. Using stock market returns in Indonesia and ranking its response to the volatility in the United States, Hong Kong, and Singapore markets, Kartika, Achsani, Manurung, and Nuryartono (2012) found that shocks to the volatility of the return of most consecutive returns are volatility in Indonesia itself, followed by Singapore, Hong Kong, and the United States. This means that changes in the Indonesian stock market are more influenced by events in Singapore than in Hong Kong and the United States. This is similar to the study by Chuang, Liu, and Susmel (2011), this time involving 10 stock markets in the Asian region. They found contemporaneous relation between trading volumes and return volatility in six out of 10 markets: Hong Kong, Korea, Singapore, China, Indonesia, and Thailand, but the negative contemporaneous correlation between trading volume and return volatility in Japan and Taiwan. Statistics from the Indonesia Investment Coordinating Board show that Singapore is Indonesia's top investor accounting for almost $90 \%$ of total foreign direct investments within ASEAN and 35\% overall as of the fourth quarter of 2010. This percentage has slightly dropped to 88\% within ASEAN and almost 20\% overall as of the fourth quarter of 2012 (Retrieved from http://www7.bkpm.go.id/contents/p16/statistics/17). Singapore is also the top tourist destination among Indonesians, with 2.3 million visitors in 2010, a year-on-year change of $31 \%$ (Retrieved from http://app.stb.gov.sg/data/tou/typea/type1/2010/16/2010vas.pdf). As of September 2012, tourist arrivals from Indonesia to Singapore have already reached the two million mark (Retrieved from http://app.stb.gov.sg/data/tou/typea/type1/2012/16/2012_vas_preliminary.pdf).

- Singapore and South Korea. The indices' returns for Singapore and South Korea show a correlation coefficient of 0.6634 which is consistent with the earlier findings of Park (2010) where Singapore had a correlation coefficient of 0.71 with South Korea. Park (2010) further explained that the major financial systems of Japan, Singapore, and Hong Kong are strongly linked to the rest of the Asian markets. However, Chuang, Lu, and Tswei's (2007) pairwise correlations of stock returns showed the strongest correlation in the full sample period is observed between Hong Kong and Singapore markets (0.5579) and Korea is the least related to the others among the other Asian markets (Japan, Hong Kong, Singapore, Taiwan, and Thailand) in the study. Figures from the Organization for Economic Cooperation and Development (OECD) show that in 2001 South Korea foreign direct investments to Singapore was estimated at US\$ 61.0 million. In 2011 this was estimated at US\$ 481.7 million. On the other hand, Singapore foreign direct investments in South Korea in 2001 were estimated at US\$ 20.0 million. By 2011, this was already at US\$ 979.9 million (Retrieved from http://stats.oecd.org/index.aspx?datasetcode=fdi_flow_partner).

- Singapore and Thailand. The findings in this research showed that the index's return to South Korea and Thailand has a correlation coefficient of 0.6588. The finding is supported by Park (2010) where Singapore had correlation coefficients of over 0.5 to other Asian countries, including Japan, Taiwan, Indonesia, India, Malaysia, and Thailand. In the first seven months of 2012, Singapore led the foreign direct investors in Thailand with projects worth over 10 billion Baht (Retrieved from http://www.Thailand-business-news.com/japan/41021-di-in-thialnad-reaches-106-5mn-in-7months). On the other hand, foreign direct investments in Thailand from Singapore were 18.75 billion Baht in 2006 and by 2011 was estimated at 25.18 billion Baht (Retrieved from http://www.boi.go.th/upload/content/t.sin11_74714.pdf).

- Philippines and Indonesia. The literature that supports this finding is not conclusive, although there are periods that indicate high correlation. For instance, Park (2010) found that while the correlation coefficients between the Philippines and Indonesia were low for the period 2005-2008, when divided for periods before 
(2005-2006) and after (2007-2008) the global financial crisis, the coefficients increased. On the other hand, Purnomo and Rider (n.d.) using monthly data from January 1997 to December 2011 showed a much higher significant relationship between the Indonesian and Philippine stock markets. The mixed results could also be attributed to the relationship between domestic consumption and market performance. According to a briefing made by Merrill Lynch Asia Pacific on July 2012:

Indonesia and the Philippines have very strong domestic consumption so it is a multi-year story. It is a favorite area. How long it will last - there would be probably a rotation. Previous analyses show that every time developed markets are weak, ASEAN especially-those with strong domestic consumption-will outperform. (Retrieved from http://ppp.gov.ph/?p=9065)

- Thailand and South Korea. Early studies on stock market return correlations between Thailand and South Korea already show a strong relationship. Chuang, Lu, and Tswei (2007) noted a high correlation (0.8595) coefficient between Thailand and Korea markets from the period January 1992 to June 2006. This finding was also seen in Nordell and Stark (2010) where they noted that the correlation between the Thailand (SET) and South Korea (KOSPI) is among the highest. The strong relationship is also explained that Thailand and South Korea are strong trading and investment partners. In 2005 total approved Korean investments in Thailand were estimated at 1.485 billion Baht and in 2010 this reached 2.572 billion Baht. The highest level of approved investments was in 2008 where it reached 9.273 billion Baht (Retrieved from http://www.boi.go.th/upload/content/kor10_40585.pdf). OECD figures show South Korea foreign direct investments to Thailand in 2011 were at US\$ 1.8 million up from US\$ 0.4 million in 2001 (Retrieved from http://stats.oecd.org/index.aspx?datasetcode=fdi_flow_partner).

- Thailand and Indonesia. Aside from the studies mentioned above, the strong correlation of the Thai and Indonesian stock markets is also not surprising since they are also strong investment partners and the same tourist destinations. According to the Royal Thai Ministry of Commerce, Indonesia is currently ranked the sixth as global trade partners with Thailand. The trade value between the two countries is worth around 17 billion US dollars in 2011. On the other hand, Indonesia ranks the sixth among Asian nations in term of visitors attending Thailand's exhibitions. Indonesia visitors accounted for 7.4 percent of total overseas visitors attending

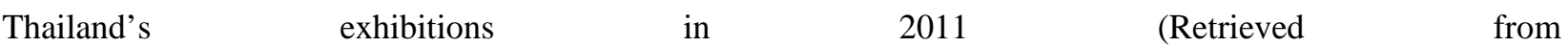
http://www.tceb.or.th/about-us/e-community/news/1563-Indonesia-Thailand-agrees-to-encourage-mutual-partn ership-in-exhibitions-and-trade-industry.html).

As an initial analysis of this close relationship we employed multiple regression with the Philippine stock returns as the dependent variable. Based on Table 6, Indonesia, Singapore, and Thailand stock market returns have a significant relationship with the Philippine stock returns. This relationship implies that stock returns and developments in the stock markets within the ASEAN 5 are closely related. It is interesting to note that Malaysia does not have a significant relationship, a view supported by Roy and Mandal (2012) where they found that it was only in the case of Malaysia foreign investment cannot be related to growth as the Malaysian economy had become self-sufficient to reap economic benefits.

In the case of the Philippines in 2011, figures show that Malaysia was the Philippines' ninth largest trading partner, with total trade amounting to $\$ 3.7$ billion, while it was the Philippines’ 11th largest export and eight largest import markets. A total Philippine exports to Malaysia were valued at $\$ 1$ billion, while imports from Malaysia during the same year amounted to \$2.6 billion (Retrieved from 
http://www.philstar.com/breaking-news/807153/kuala-lumpur-hold-philippines-malaysia-investment-forum)

The unit root test was used to determine the presence of integration and the results show that there is co-integration with Philippine index's returns and the indices' returns of Indonesia, Singapore, and Thailand. The unit root tests determined the degree of integration that was established earlier in the correlation coefficients of Tables 4 and 5. Table 7 further validates the presence of integration in the Philippines and Indonesia, Singapore, and Thailand. The results of the study are similar to Chittedi (2010) where there was evidence of co-integration among the BRIC countries and developed countries, US, UK, and Japan. In the case of the ASEAN 5, there is co-integration among the four countries.

Table 6

Model 1: Heteroskedasticity-Corrected, Using Observations From January 2000 to April 2012 (T = 148); Dependent Variable: Pseilnreturn

\begin{tabular}{|c|c|c|c|c|}
\hline Variables & Coefficient & Std. Error & $t$-ratio & $p$-value \\
\hline Const & 0.00223612 & 0.00399525 & 0.5597 & 0.57658 \\
\hline JCIln_returns & 0.309844 & 0.0768826 & 4.0301 & $0.00009^{* * *}$ \\
\hline KLCLNRET & -0.000930629 & 0.0872891 & -0.0107 & 0.99151 \\
\hline KospilnrET & -0.0101797 & 0.0788902 & -0.1290 & 0.89751 \\
\hline Nikkeilnreturns & -0.0831202 & 0.0888601 & -0.9354 & 0.35119 \\
\hline Shanghailnretun & 0.0314304 & 0.0488555 & 0.6433 & 0.52106 \\
\hline $\begin{array}{l}\text { Singaporelnretu } \\
\text { Setlnreturn }\end{array}$ & $\begin{array}{l}0.277279 \\
0.136026\end{array}$ & $\begin{array}{l}0.0982754 \\
0.0801303\end{array}$ & $\begin{array}{l}2.8215 \\
1.6976\end{array}$ & $\begin{array}{l}0.00548^{* * *} \\
0.09181^{*}\end{array}$ \\
\hline \multicolumn{5}{|c|}{ Statistics based on the weighted data } \\
\hline Sum squared resid & 472.4303 & \multicolumn{2}{|c|}{ S.E. of regression } & 1.836982 \\
\hline$R$-squared & 0.498630 & \multicolumn{2}{|c|}{ Adjusted $R$-squared } & 0.473562 \\
\hline$F(7,140)$ & 19.89070 & \multicolumn{2}{|l|}{$P$-value $(F)$} & $2.45 e-18$ \\
\hline Log-likelihood & -295.8931 & \multicolumn{2}{|c|}{ Akaike criterion } & 607.7861 \\
\hline Schwarz criterion & 631.7638 & \multicolumn{2}{|c|}{ Hannan-Quinn } & 617.5282 \\
\hline Rho & -0.139268 & \multicolumn{2}{|c|}{ Durbin-Watson } & 2.276038 \\
\hline \multicolumn{5}{|c|}{ Statistics based on the original data } \\
\hline Mean dependent var & 0.005949 & \multicolumn{2}{|c|}{ S.D. dependent var } & 0.066515 \\
\hline Sum squared resid & 0.328042 & \multicolumn{2}{|c|}{ S.E. of regression } & 0.048406 \\
\hline
\end{tabular}

Note. ${ }^{*}$ Significant at $10 \%$ level; ${ }^{* * *}$ Significant at $1 \%$ level.

The research is similar to the methodologies used by Savva and Aslanidis (2008), i.e., co-integration, Engle-Granger, and GARCH $(1,1)$. In this research, we followed Bollerslev $(1986)$ GARCH $(1,1)$ specification for the time series data-indices' returns.

Table 8 shows the results of GARCH $(1,1)$ for pseilnreturn. The significant high alpha (1) value $(0.08)$ indicates presence of volatility clustering in the stock markets. This means volatilities in the returns exist in one period to the next. The high beta (1) value (0.88) in Table 8 means that volatility is affected by changes in the stock market. Results in Table 8 are supported by the literature provided by Savva and Aslanidis (2008) where GARCH equations indicate the betas are normally between 0.80 and 0.95 and the alphas are estimated to be between 0.07 and 0.15. Furthermore, Table 8 shows that the $p$-value is not significant in the Philippine stock exchange returns. However, the Philippine stock exchange index's returns have significant relationships with Indonesia, Singapore, and Thailand. These findings are consistent with the regression and co-integration model results. The high value in alpha and beta and the significant relationships of the Philippine stock exchange with 
Indonesia, Singapore, and Thailand may indicate that there is evidence of spillovers among these stock markets, and some interactions are present among them. The results are similar to an earlier study of Kabigting and Hapitan (2011) where there is volatility clustering in the ASEAN 5 stock and currency markets. The findings also show quicker reaction to information (as indicated by high beta value) within these markets and across the region. This is an indication of increased interdependence within the ASEAN 5 countries.

Table 7

Co-integrating Regression-OLS, Using Observations From January 2000 to April 2012 ( $T=148$ ); Dependent Variable: Pseilnreturn

\begin{tabular}{lcccc}
\hline Variables & Coefficient & Std. error & $t$-ratio & $p$-value \\
\hline Const & 0.000490586 & 0.00406640 & 0.1206 & 0.9041 \\
JCIln_returns & 0.291558 & 0.0790995 & 3.686 & $0.0003^{* * *}$ \\
KLCLNRET & -0.0509655 & 0.102883 & -0.4954 & 0.6211 \\
KospilnrET & 0.0592135 & 0.0789913 & 0.7496 & 0.4547 \\
Nikkeilnreturns & -0.0537486 & 0.0888423 & -0.6050 & 0.5462 \\
Shanghailnretun & 0.0140029 & 0.0523836 & 0.2673 & 0.7896 \\
Singaporelnretu & 0.285335 & 0.106384 & 2.682 & $0.0082^{* * *}$ \\
Setlnret & 0.190488 & 0.0759661 & 2.508 & $0.0133^{* *}$ \\
Mean dependent var & 0.005949 & S.D. dependent var & 0.066515 \\
Sum squared resid & 0.317776 & S.E. of regression & 0.047643 \\
$R$-squared & 0.511385 & Adjusted $R$-squared & 0.486954 \\
Log-likelihood & 244.6251 & Akaike criterion & -473.2501 \\
Schwarz criterion & -449.2724 & Hannan-Quinn & -463.5080 \\
Rho & -0.154497 & Durbin-Watson & & 2.308329 \\
\hline Note; Significan & & \\
\hline
\end{tabular}

Note. $^{* * *}$ Significant at 5\% level; ${ }^{* * *}$ Significant at 1\% level.

Table 8

Model 1: GARCH, Using Observations From January 2000 to April 2012 ( $T=148)$; Dependent Variable: Pseilnreturn Standard Errors Based on Hessian

\begin{tabular}{lcccc}
\hline Path & Coefficient & Std. Error & \multicolumn{1}{l}{ z } & -value \\
\hline Const & 0.00232393 & 0.00386464 & 0.6013 & 0.54762 \\
JCIln_returns & 0.328063 & 0.0790952 & 4.1477 & $0.00003^{* * *}$ \\
KLCLNRET & -0.0372018 & 0.103197 & -0.3605 & 0.71848 \\
KospilnrET & 0.0313281 & 0.0807885 & 0.3878 & 0.69818 \\
Nikkeilnreturns & -0.0785755 & 0.0826307 & -0.9509 & 0.34164 \\
Shanghailnretun & 0.00371198 & 0.0499475 & 0.0743 & 0.94076 \\
Singaporelnretu & 0.303607 & 0.113899 & 2.6656 & $0.00769^{* * *}$ \\
Setlnret & 0.189944 & 0.0728462 & 2.6075 & $0.00912^{* * *}$ \\
Alpha (0) & $5.51575 e-05$ & 0.000116233 & 0.4745 & 0.63511 \\
Alpha (1) & 0.0837315 & 0.0577072 & 1.4510 & 0.14679 \\
Beta (1) & 0.886809 & 0.0636615 & 13.9301 & $<0.00001^{* * *}$ \\
Mean dependent var & 0.005949 & & S.D. dependent var 0.066515 \\
Log-likelihood & 245.9928 & & Akaike criterion & -467.9856 \\
Schwarz criterion & -432.0191 & & Hannan-Quinn & -453.3725 \\
& & & & \\
\hline
\end{tabular}

Note. Unconditional error variance $=0.00187234 ;{ }^{* * * *}$ Significant at $1 \%$ level. 


\section{Conclusions and Areas for Further Study}

In the past 10 years, the stock markets of ASEAN $5+3$ have become increasingly integrated as well as among certain pairs of countries. Our findings show that the Philippine stock exchange together with Indonesia, Singapore, and Thailand may indicate that there is evidence of spillovers among these stock markets, and some interaction is present among them. This means that any news in any of these stock markets may increase volatilities not only in the country but also in the region. The ASEAN 5 countries have undertaken financial reforms to provide safety nets to another financial crisis. Furthermore, the increase in financial integration among the ASEAN $5+3$ enhances competitiveness and cooperation, but it also entails possible contagion risks. Increasing integration allows better investment opportunities within and across the region. Policies must be made to further breakdown non-financial barriers such as legal requirements on ownership of stocks and businesses in general so that the region can move even more forward in the next decade of the new millennium. In the most recent development (April 2013), the ASEAN stock markets conducted a road show that will integrate their markets by 2015.

In the case of the Philippines, there might be a need to explore more investment opportunities with its neighbors (for instance with Malaysia) so that there can be increased flow of investments among these two countries. Also, there could be further research on the factors that cause the integration between some countries and not the whole ASEAN $5+3$.

\section{References}

Ahmed, S., \& Farooq, O. (2008). The effect of 9/11 on the stock market volatility dynamics: Empirical evidence from a front line state. International Research Journal of Finance and Economics, 16, 71-83.

Bollerslev, T. (1986). Generalized autoregressive conditional heteroskedasticity. Journal of Econometrics, 31, 307-327.

Chittedi, K. (2010). Global stock markets development and integration: With special reference to BRIC countries. International Review of Applied Financial Issues and Economics, 2(1), 18-36.

Chuang, I., Lu, J., \& Tswei, K. (2007). Interdependence of international equity variances: Evidence from East Asian markets. Emerging Markets Review, 8, 311-327.

Chuang, W., Liu, H., \& Susmel, R. (2011). The bivariate GARCH approach to investigating the relation between stock returns, trading volume, and return volatility. http://www.cba.uh.edu/rsusmel/Academic/bivariate\%20garch\%20ret\%20vol.pdf

Curto, J. D., Pinto, J. C., \& Tavares, G. N. (2009). Modeling stock markets' volatility using GARCH models with normal, student's and stable paretian distributions. Stat Papers, 50, 311-321.

Jang, H. B. (2011). Financial integration and cooperation in east Asia: Assessment of recent developments and their implications. Retrieved from http://www.imes.boj.or.jp

Kabigting, L., \& Hapitan, R. (2011). ASEAN 5 stock markets, currency risk and volatility spillover. Journal of International Business and Research, 10(3), 63-84.

Karim, B., \& Majid, M. (2010). Does trade matter for stock market integration? Studies in Economics and Finance, 27(1), 47-66.

Kartika, T. R., Achsani, N. A., Manurung, A. H., \& Nuryartono, N. (2012). Transmission of stock return volatility in Indonesia (IHSG) towards USA (DJIA), Hongkong (HSII), and Singapore (STI). Finance and Banking Journal, 14(1), 16-29.

Morana, C. (2008). International stock markets comovements: The role of economic and financial integration. Empirical Economics, 35, 333-359.

Nordell, E., \& Stark, C. (2010). Diversifying in the integrated markets of ASEAN + 3-A quantitative study of stock market correlation. Retrieved from http://www.umu.diva-portal.org/smash/get/diva2:322334/FULLTEXT0

Park, J. (2010). Comovement of Asian stock markets and the U.S. influence. Global Economy and Finance Journal, 3(2), 76-88. 
Purnomo, B., \& Rider, M. W. (n.d.). Domestic and foreign shocks and the Indonesian stock market: Time series evidence. Retrieved from http://www.frbatlanta.org/documents/news/conferences/12intdev/12intdev_PurnomoRider.pdf

Quinn, D., Schindler, M., \& Toyoda, A. M. (2011). Assessing measures of financial openness and integration. IMF Economic Review, 59(3), 488-522.

Rizavi, S., Naqvi, B., \& Rizvi, S. (2011). Global and regional financial integration of Asian stock markets. International Journal of Business and Social Science, 2(9), 82-93.

Roy, S., \& Mandal, K. (2012). Foreign direct investment and economic growth: An analysis for selected Asian countries. Journal of Business Studies Quarterly, 4(1), 15-24.

Savva, C., \& Aslanidis, N. (2010). Stock market integration between new EU member states and the Euro-zone. Empirical Economics, 39, 337-351. 